\title{
An Investigation of Relationship among Emotional Intelligence, Organizational Commitment and Job Satisfaction: Evidence from Academics in Brunei Darussalam
}

\author{
Afzaal H. Seyal ${ }^{1} \&$ Taha Afzaal ${ }^{2}$ \\ ${ }^{1}$ Faculty of Business \& Computing, Institute of Technology Brunei, Brunei Darussalam \\ ${ }^{2}$ Freelancer HR consultant and researcher, Perth, Western Australia, Australia \\ Correspondence: Afzaal H. Seyal, Faculty of Business \& Computing, Institute of Technology Brunei, Brunei \\ Darussalam. E-mail: afzaal.seyal@itb.edu.bn
}

Received: December 31, 2012

Accepted: February 5, 2013

Online Published: February 25, 2013

doi:10.5539/ibr.v6n3p217

URL: http://dx.doi.org/10.5539/ibr.v6n3p217

\begin{abstract}
Emotional Intelligence (EI) is emerging paradigm discussed and researched widely within the domain of organizational behavior and leadership research continuum in the workplace. This has further been recognized as an effective tool along with organizational commitment (OC) in assessing the job satisfaction. Keeping in view the relative importance and the potential of these two domains; EI and OC to the job satisfaction among academics, this pioneering study was conducted among the 90 academic staff of a technical university in Brunei Darussalam. The study using survey methodology aims not only to establish empirical evidence of examining academics' relationship between EI, and OC but also to find out their level of job satisfaction. The result indicates that two out of seven dimensions of EI and effective component of organizational commitment strongly predict the job satisfaction. The results are discussed and recommendations are made based upon the data analysis and conclusion.
\end{abstract}

Keywords: emotional intelligence, organizational commitment, academics, job satisfaction, Brunei Darussalam

\section{Introduction}

In today's competitive business environments, organizations are facing multifaceted challenges not only in enhancing the productivity but also coping with the pressure of setting efficient and effective human resources (HR) practices in the form of hiring, training and retaining skillful employees. To support this, effective HR policies are becoming mandatory for the success of an organization and to overcome these challenges, management of these organizations are finding new avenues of implementing effective and dynamics HR policies. In this regards, new dimensions of organizational behavior such as understanding the emotional intelligence of the employees, integration of work design characteristics, employee commitment and employee satisfaction have gained rapid prominence on the strategic roadmap of the organization.

Over the last decade, the term Emotional Intelligence (EI) emerged globally among the gurus of organizational behavior and industrial psychologists and were given due recognition by the industry. Later on, it has become one of the popular topics of many discussions, researchers, scholars, academics and corporate executives. EI is defined as ability both to know one's own emotions and to read others' emotions as well (Davies et al., 1998; Zadel, 2008). Several scholars use the term to express emotional awareness, accurate self-analysis, self-confidence, trustworthiness, conscientiousness, adaptability, innovation, and so on (Bar-On \& Parker, 2000; Goleman, 1998). However, Goleman (ibid) has assessed the link between emotional intelligence and leadership. Goleman focused on the personal capabilities of the leaders that appeared to drive outstanding performance within these organizations. Personal capabilities were clustered in three categories: technical skills, such as accounting and engineering; cognitive skills like analytical reasoning; and competencies demonstrating emotional intelligence such as the ability to work with others and effectiveness in leading change. The result showed that EI proved to be twice as important as technical skills and cognitive abilities for leadership jobs at all levels of an organization. Goleman, (1998) then listed five components of emotional intelligence that an effective leader exhibits: Self-awareness, self-regulation, motivation, empathy, and social skills. Research on emotions in the workplace suggests that emotions may drive productivity gains, innovations, and 
accomplishments of individuals, teams and organizations (Cooper, 1997). Individuals with high emotional intelligence are said to be more effective at leading and managing others and fostering positive attitudes amongst employees (George, 2000).

Despite of the management crisis in Asia and other parts of third world countries, EI was given due consideration in dealing with the issues of low organizational productivity and resolving HR related practices especially focusing on employee turnover and issues dealing with job satisfaction. Researchers have conducted studies by linking several antecedent variables such as organizational commitment, motivation and organizational culture. However, little research endeavors in South-east Asia has been devoted to examine and understand its application and practicality not only among businesses but especially among the academics of a higher learning institutions. The academics of the universities behave entirely different contrary to the corporate executives cum leaders in the business organizations. Most of the work as stated above has been conducted in the western world and their results might not be generalized within the corporate world among the South-east Asian context. There exists a potential gap in adopting the results of these researches on the leadership continuum with ASEAN business community. This pioneering research therefore aims not only to provide empirical evidence of examining the link between emotional intelligence, organizational commitment and job satisfaction among the academics of a technical university in Brunei Darussalam, but also to predict the job satisfaction with the significant dimensions of the emotional intelligence and of organizational commitment.

The paper begins with the introduction that also gives some explanation on the motivation of the study with a brief review of literature on the three variables selected for the study. This is followed by a discussion of the methodology and presentation of the findings and results. The results are discussed and finally conclusions and practical implications of the study are highlighted.

\subsection{Motivation to Conduct the Study among Academics}

The majority of studies on EI and organizational commitment has been undertaken in the business or in the industrial setting (Muller et al., 1992); comparatively less has been researched within the educational setting. The education sector, especially the higher education plays a pivotal role in the national development. One of the biggest problems faced by the universities especially in the developing nations is lack of organizational commitment of their faculty members. This has resulted in the lack of concern among faculty members towards achieving the university's goals and delivering knowledge to the students and ultimately resulting in low participation of students and high turnover of university faculty members (Sial et al., 2011). Similarly, a fair number of studies like Batt, (2002); Huselid, (1995); Patterson et al. (1995) linked HR practices with number of outcomes including job performance, productivity, absenteeism, turnover and focus remained on the attitude of the employee toward their commitment. Sial et al., (2011) have found that organizational commitment is strongly and positively influenced by the compensation practice among university staff. Studies have also found that fostering organizational commitment among the academic staff is very important as the academics that are highly committed stay longer, perform better, miss less work and engage in more positive behavior (Chughtai \& Zafar, 2006). Nooraei and Arasi, (2011) studied 896 academics in Iran and found a strong relationship between faculty's social competence and their academic performance. On the other hand, academic staff that is not committed to their workplace put less efforts thus in resulting lower performance in students' learning in particular and lowering of the education standard in general. From the administration point of view the good staff take with them teaching as well research skill and experience that is deemed necessary not only for staff development but also to improve the university rating. The committed faculty would further cut down the cost and time involved in advertising expenses, in recruitment, selection and training of new faculty members. Thus the replacement cost could be minimized with the retention of more committed and satisfied existing faculty members. In his study, Buck (1999) quoted from the David Morris of Morris \& Associate (USA) that the average cost of replacing a professional employee making $\$ 15$ an hour is US $\$ 5190$ (Nov, $\left.6^{\text {th }}, 1998\right)$. The cost is even higher in the higher education institution, considering the funding process, their average annual turnover among staff employee at public research institution is approximately $17 \%$ (Buck \& Watson, 2002).

Malik et al. (2010) in their study of job satisfaction and organizational commitment among 331 academic staff of public sector universities in Pakistan found that satisfaction with work itself, quality of supervision and pay satisfaction had significant positive influence on organizational commitment. Daneshfard and Ekvaniyan, (2012) studied organizational commitment and job satisfaction in Iran and found a correlation between faculty job satisfaction with affective and normative organizational commitment $(r=.25, \mathrm{p}<0.05)$. Gaylor, (2004) found in his study of faculty members at a Christian university in USA that affective commitment was found to be a significant predictor of intention to leave. So if the faculty members have a sense of affection to the mission of college they tend to stay within the university because they "want to" stay. In another study of 122 faculty 
members in a Taiwanese' university, it was found that faculty that possessed higher commitment score had a higher level of job satisfaction (Chien \& Chen, 2012).

In summary, it is evident that by conducting studies that combine the important antecedent variables with job satisfaction among faculty members will not only improve the total variance shared in job satisfaction but also provide guidelines for the relevant authorities at the higher education sector to come up with policies that will enable to attract and retain top level faculty members in the universities. From the researchers' point of view, adding more organizational variables like emotional intelligence will not only improve the parsimony of the research conducted but also fill-in the existing gaps with the various regional and geographical setting. That's why it is very important to study these variables in depth to find out the empirical support.

\section{Review of Literature}

\subsection{Emotional Intelligence}

Much more has been written on the EI over the past ten years (Davies et al., 1998). Salovey and Mayer (1990) initially proposed a definition of EI as a set of skills and abilities contributing to the appraisal of emotions, the regulation of emotions, and the use of emotions in reasoning. Goleman $(1995,1998)$ has assessed the link between emotional intelligence and leadership ability. As stated previously, Goleman (1998) listed five components of emotional intelligence that an effective leader exhibits: self-awareness, self-regulation, motivation, empathy and social skills. Prior research on emotions in the workplace suggests that emotions may drive productivity gains, innovations and accomplishments of individuals, teams, and organizations (Cooper, 1997). Similarly, Bedwell (2003) have studied the relationship between emotional intelligence and personality and job performance and found several of the EI subscales have a significant relationship with job performance after controlling personality feature anxiety. Eskandarpour and Amiri (2012) also studied the relationship between various dimensions of emotional intelligence and effectiveness of forty-four university managers and noticed a significant difference between different dimensions of EI and their effectiveness.

Studies on EI are nevertheless exuberant; however, not much has been studied in academic settings. Most of the prior studies were confined to academics' leadership in linking their emotional intelligence with their job performance. Porter et al. (1974) summarized the abundant literature showing the consistent and moderate relationship between greater job satisfaction and their propensity to remain with the organization. Goleman, (1998) stressed that high emotional awareness has been considered as an important trait for workplace setting. Dong and Howard (2006) found that emotionally intelligent behavior positively affects job satisfaction. In the educational setting, Indoo and Ajeya (2012) found among faculty members in India a significant negative relationship between emotional intelligence and occupational stress. Jelondar and Goodare (2012) studied the teachers' emotional intelligence and job satisfaction in Iran and confirmed the strong correlation that existed between two variables. Wright and Crapanzano, (2000) linked the EI with workplace setting. Sy, Tramm and O'Hare (2006) asserted that individuals with high emotional intelligence demonstrated higher measures of job satisfaction.

In Brunei a number of studies were undertaken to find the correlation between employees' emotion and EI of the employees during change (Salleh, 2010), linking leadership and EI (Salleh, 2009) and finally assessing EI during change (Salleh, 2008). Seyal et al. (2011) in their first study of 110 senior executives of SMEs in Brunei have studied the relationship between leadership style, emotional intelligence, personality, and organizational culture and found that there exists a significant relationship between EI, leadership style (transformational) and personality dimension dependence versus autonomous remained significant. Similarly in another study Seyal et al. (2012) not only studied the emotional intelligence and organizational citizenship behavior among executives of Bruneian SMEs but also studied the role of the demographics on EI. The results indicated that both EI and OCB are significantly correlated and all demographical variables excluding gender are significant with EI of the executives. The results of all these studies highlighted the importance and role of EI on different scenarios within the general context of Brunei Darussalam.

\subsection{Organizational Commitment}

Organizational commitment is commonly defined as a "psychological link between the employee and his/her organization that makes it less likely that employee will voluntarily leave the organization (Allen \& Meyer, 1996). The organizational commitment is no doubt one of the most researched topic in organizational behavior and human resource management but is also an essential concern in organizational and industrial psychology because of its relationship with many of the employees behavior and attitude as employees satisfaction (Tanriverdi, 2008), job performance and quality of work (Hacket et al., 1994). 
The organizational commitment (OC) has been extensively researched as an important factor in employee's motivation, retention and satisfaction. Measuring organizational commitment is multi-dimensional concept and is complex work attitude (Allen \& Meyer, 1996). However, two dimensions of OC, effective commitment and continuance commitment were of significant nature. According to Moynihan, Boswell and Boudreau, (2000) effective commitment refers to identification with, involvement in, and emotional attachment to the organization. Previous work has found that both job characteristics and job satisfaction are statistically significantly related to affective commitment. Whereas, continuance commitment refers to commitment based on the employee's recognition of the costs associated with leaving the organization such as loss of benefits and few employment alternatives. According to Meyer and Allen (1991) affective commitment is a sense of belonging and identification that increases the employees' involvement in the organization' goal and their desire to remain with the organization as thus, is considered as an important determinant of dedication and loyalty. Both job characteristics and job satisfaction are statistically significant with affective commitment. Simply speaking, employees with high affective commitment stay with the organization because they want to do so, compared with employees who have high continuance commitment who stay with the organization because they have to do so (Allen \& Meyer, 1990). The significance of organizational commitment has been focused on its relation to many behavioral and attitudinal consequences among employee that influence the organization such as, job performance and job satisfaction (Jofri et al., 2011; Malik et al., 2010; Daneshfard \& Ekvaniyan, 2012), job turnover (Buck \& Watson, 2002), organization and job productivity and performance (Saif et al., 2012), organizational citizenship behavior (Gautam et al., 2005; Meyer, Stanley, \& Herscovitch, 2002).

\subsection{Job Satisfaction}

Job satisfaction is another important criteria that has been investigated not only under organizational behavior but by several other disciplines such as organizational and industrial psychology and management sciences. Locke, (1976) defined job satisfaction as a 'pleasure or positive emotional state resulting from the appraisal of one's job or job experience'. Whereas, Porter et al. (1975) noted that job satisfaction is determined by the difference between the amounts of some valued outcome that a person receives and the amount of the outcome he feels he should receive. Job satisfaction is actually how much a person likes his/her job (Spector et al., 1998). Similarly, Smith et al. (1998) asserted that job satisfaction is an effective reaction to a job that results from the incumbent's comparison of actual outcome with those which are desired.

\subsection{Relationship between Emotional Intelligence, Organizational Commitment \& Job Satisfaction}

Although a lot of studies have focused on linking emotional intelligence, organizational commitment and job satisfaction among the business enterprises, unfortunately not much has been done among academics; whilst several studies were undertaken in the developing countries. Santhaparaj and Alam (2005) and Ngah et al., (2009) in their Malaysian-based study of emotional intelligence of university staff with respect to work attitude found that EI is positively related to work attitude and appraisal and expression of emotions are moderately correlated with job performance and satisfaction. Ssesanga and Garrett, (2005) studied the job satisfaction among the university academia in Uganda and found evidence of job satisfaction among university employees and antecedent variables EI, and organization commitment. The result suggested that academics with high values of emotional intelligence and perceived high satisfaction tend to feel more emotionally attached with their organizations. Similarly, Lee (2010) studied the relationship between job characteristics and job satisfaction towards affective commitment among engineers of an engineering firm in Malaysia and found that they were related to effective commitment. Shore and Martin, (1989) studied organizational commitment and found that it was strongly related to job performance rather than job satisfaction. This might be because of different measures to assess the self-report responses used for this study. Previous studies have found the relationship between OC and EI mainly among leaders of the business organizations in determining their leadership style. Furthermore, these studies were diverse in their nature as some studies were regionally based while others have focused on a particular industry such as hotel or banking sectors. Carmeli (2003) and Petrides and Furham, (2006) examined the three components of EI, organizational commitment and job satisfaction and found significant relationship existed among them. Arifin et al. (2004) studied the influence of EI, OC, job satisfaction in the public and private sectors and confirmed the significant relationship among these variables. Khani-M and Lalardi, (2012) studied the emotional intelligence, organizational commitment among staff of the hospitality industry in Iran. Results show that there was a significant relationship between EI and OC.

\section{Methodology}

\subsection{Instrument}

A multidimensional instrument in four parts was used for this study to capture the information on emotional 
intelligence, organizational commitment and job satisfaction using the five-point Likert scale. The demographical data was provided in Part one of the questionnaire and consists of questions based upon nominal and ordinal scale. The detail on basic demographical data is given in Table 2.

\subsection{The Measures}

Measuring Emotional Intelligence is multi-dimensional concept. There are three models that are commonly used in the literature (Caruso, 2004). These are "ability-based' that measures the mental ability to do with emotions used by Mayer and Salovey, (1997). The second one is "trait-based" that focuses on socio-emotional traits such as "awareness". Barr-on (1997) has used this model and finally the "competency-based" model that measures the set of emotional competencies and used by Goleman, (2001). However, for this study, Emotional Intelligence were measured on a scale provided by Genos (www.genos.com.au) developed by Palmer and Stough, (2001) and was based on Swinburne University Emotional Intelligence Test (SUEIT). The SUEIT, however, measures five components of EI. The Genos EI concise version consisting of 31-items yield a total EI score and was sub-divided into seven subscales. The SUEIT dimension "recognition and expression" was further subdivided into two of Genos' version into emotional self-awareness and emotional expression. The emotional management component of SUEIT was subdivided into self-management and emotional management of others in the Genos' instrument (Palmer, 2007). The selection of the Genos' instrument is simply because of having sufficient face validity, easy to understand, relatively cheaper and require less time to fill-in the questionnaire. Table 1 further elaborates the seven subscales of the "Emotional Intelligence" scale.

Table 1. Showing the explanation of sub-scales of Genos EI measure

\begin{tabular}{|c|c|}
\hline Subscale & Explanation \\
\hline Self-awareness & $\begin{array}{l}\text { Understanding ones' own feelings and use of those priorities to lead oneself in decision making to do } \\
\text { one realistic examination of one's own capabilities and self-confidence. }\end{array}$ \\
\hline Emotional expression & $\begin{array}{l}\text { Using the deepest interest to move and lead towards purposes help us to proceed in the way of } \\
\text { competence and lead us to resistance against weaknesses and regression. }\end{array}$ \\
\hline $\begin{array}{l}\text { Self-control \& emotional self- } \\
\text { management }\end{array}$ & $\begin{array}{l}\text { Being compatible with ones' own emotions in a way that instead of interference in action help } \\
\text { themselves to facilitate and capability of appropriate interaction with changes. }\end{array}$ \\
\hline $\begin{array}{l}\text { Emotional awareness of others and } \\
\text { emotional management of others }\end{array}$ & $\begin{array}{l}\text { Understanding feeling of others, capability of considering others' viewpoint the way of interacting } \\
\text { with individuals' emotional responses and developing compatibility with different people. }\end{array}$ \\
\hline Emotional reasoning & $\begin{array}{l}\text { Being compatible with sentiments in relations and careful understanding of situation and social } \\
\text { network. }\end{array}$ \\
\hline
\end{tabular}

Organizational Commitment was measured on a sixteen-item scale and adopted after Myers and Allen, (1991) an example being "I feel emotionally attached to this organization".

Job Satisfaction was measured on a three-item scale adopted from Hackman and Oldman's (1975), measured on a five-point Likert scale. An example of the first item is "I find real enjoyment in my job".

\subsection{The Population and Sample}

The study is descriptive and of an exploratory nature. The target population in this study is all the academics in both the faculty of business and computing and faculty of engineering. Keeping in view the small size of the population, the study was designed to cover the whole population. This is not a new phenomenon as Sharon, (2009) has identified two aspects of examples that illustrate when total population sampling may be appropriate: (1) the population size is relatively small and (2) the population shares an uncommon characteristic. In our case, the uncommon characteristic is academics from the different faculties and departments. Based on this assertion, one hundred and thirty questionnaires were sent to the academics of a technical university in the capital area. Out of them 100 questionnaires were returned. Ten of them were found not to be filled-in properly and were dropped from the final stage. The responses of 90 were retained making the response rate $69 \%$, sufficient enough to draw a logical conclusion. The basic statistics and reliability coefficient are provided in the Table 3.

\section{Results}

Data obtained from the survey were analyzed using descriptive statistics, factor analysis as well as correlation and regression analysis by using SPSS version 17, a well-known statistical package.

\subsection{Background Profile}

The background data of academics, as well as their organizational profile is summarized in Table 2. The Table 2 describes the characteristics of respondents. Majority is relatively young male academics within age group of 
25-40 years and possesses 15 years and above of teaching experience. Similarly majority of the respondents are lecturers (55\%) and from Electrical \& Communications Engineering department (21\%).

Table 2. Demographical data

\begin{tabular}{lll}
\hline Variable & Description & Percentage \\
\hline Gender & Male & $64 \%$ \\
& Female & $36 \%$ \\
\hline Age & Between 25-35 & $40 \%$ \\
& Between 36-40 & $18 \%$ \\
\hline Position & Above 40 & $42 \%$ \\
\hline Educational Qualifications & Lecturers & $55 \%$ \\
& Senior Lecturers & $31 \%$ \\
& PL/Assoc Prof & $6 \%$ \\
\hline Departmental Affiliation & Advanced Tech. Diploma & $7 \%$ \\
& First Degree & $14 \%$ \\
& Masters Degree & $58 \%$ \\
& PhD & $21 \%$ \\
\hline No of Years of Experience & Business Management & $12.5 \%$ \\
& Computing & $17 \%$ \\
& Petroleum \& Chemical & $6 \%$ \\
& Electrical \& Comm Engg & $21 \%$ \\
& Civil Engineering & $18 \%$ \\
& Mechanical Engineering & $19 \%$ \\
\hline
\end{tabular}

\subsection{Validity and Reliability}

In order to assess the validity and reliability, tests were performed in this study. For getting the reliability of the questionnaire the coefficient of Cronbach's alpha (1951) were taken into account. For the various subscales of emotional intelligence the minimum Cronbach's alpha value is above 0.70, except for the one (.68) indicates sufficient reliability of the instrument and fulfill the criteria of Hair et al. 1998. The Cronbach's coefficient for organizational commitment is .88 for affective and .86 for continuance subscale which is higher than original scale reliability of $87 \%$ and $75 \%$ (Meyer \& Allen, 1991).

During the initial screening of conducting reliability tests the items were dropped because of low corrected-item total correlation which was less than .40, the cut-off value suggested (Hair et al., 1998). The remaining items were applied the factor analysis subjected to principal component analysis using varimax rotation, in addition to considering Kaiser-Normalization as techniques of rotation to examine both the individual items and the relationship among them (Hair et al., 1998). All the items that were loaded on more than one factor at cut-off value of .40 were eliminated from the constructs (The result of the factor analysis is not attached to avoid the unnecessary length of the paper). Convergent and discriminant validities were assessed via factor analysis by taken in the account the total variance as explained by each construct. Table 4 shows the inter-constructs correlation and diagonal in the Table represents the variance. The variance above 0.50 suggests a sufficient validity and parsimony of the instrument. The internal consistency (Cronbach's alpha) of this instrument and its subscales and the alpha value is provided in Table 3.

Prior to the testing for the regression analysis, in line with the principles of multivariate data analysis, we conducted a zero order correlation between the various independent variables as shown in Table 4 . The correlation provides directional support for the predicted relationship and shows that co-linearity among the independent variables are within the acceptable range (Hair et al. 1998). 
Table 3. Reliability \& quality control statistics

\begin{tabular}{lllllll}
\hline & Mean & $\begin{array}{c}\text { Std } \\
\text {.dev }\end{array}$ & $\begin{array}{l}\text { Cronbach } \\
\text { Alpha( } \boldsymbol{\alpha})\end{array}$ & Original items & Items retained & Source \\
\hline Emotional Self Awareness & 3.57 & 1.07 & .78 & 4 & 4 & Palmer \& Stough, (2001) \\
& & & & & 5 & \\
Emotional Expression & 3.39 & 1.07 & .68 & 5 & 4 & (ibid) \\
Emotional Awareness of Others & 3.65 & 1.08 & .70 & 4 & 5 & \\
Emotional Reasoning & 3.51 & 0.89 & .72 & 5 & 4 & \\
Emotional Self Management & 3.49 & 1.06 & .70 & 5 & 4 & Meyer \& Allen, (1991) \\
Emotional Management of others & 3.56 & 1.03 & .70 & 4 & 4 & (ibid) \\
Emotional Self Control & 3.30 & 1.04 & .72 & 4 & 4 & Heckman and Oldman's (1975) \\
Affective Org. Commitment & 3.31 & 1.10 & .88 & 8 & 3 & \\
Continuum Org. Commitment & 3.04 & 1.07 & .86 & 8 & & \\
Job Satisfaction & 3.74 & 1.12 & .90 & 3 & & \\
\hline
\end{tabular}

Table 4. Showing inter-constructs correlation

\begin{tabular}{|c|c|c|c|c|c|c|c|c|c|c|}
\hline Constructs & 1 & 2 & 3 & 4 & 5 & 6 & 7 & 8 & 9 & 10 \\
\hline Emotional self awareness (1) & 1.00 & & & & & & & & & \\
\hline Emotional expression (2) & $.26^{*}$ & 0.64 & & & & & & & & \\
\hline Emotional awareness of others (3) & $.61^{*}$ & $.50^{*}$ & 0.60 & & & & & & & \\
\hline Emotional reasoning (4) & $.32^{*}$ & $.38^{*}$ & $.38^{*}$ & 0.60 & & & & & & \\
\hline Emotional self management (5) & .38 & .60 & $.55^{*}$ & $.30^{*}$ & 0.58 & & & & & \\
\hline Emotional management of others (6) & $.29^{*}$ & $.46^{*}$ & $.53^{*}$ & $.52^{*}$ & .15 & 0.59 & & & & \\
\hline Emotional self control (7) & 54 & .29 & .58 & .11 & $.35^{*}$ & $37^{*}$ & 0.55 & & & \\
\hline Affective-org. commitment (8) & .29 & .14 & .16 & .17 & .12 & $.32^{*}$ & $.38^{*}$ & 0.57 & & \\
\hline Continuum-org. commitment (9) & .11 & .04 & -.02 & .16 & .06 & .10 & .20 & $.38^{*}$ & 0.55 & \\
\hline Job satisfaction $(10)$ & .08 & .23 & .22 & .19 & $.36^{*}$ & $.23^{*}$ & $.54^{*}$ & $.25^{*}$ & .10 & 0.60 \\
\hline
\end{tabular}

Notes: Diagonal represents the total variance explained. * shows significant values at $\mathrm{p}<0.05$.

\subsection{Regression Analysis}

Regression analysis was conducted not only to find out the relationship between the nine independent variables on the emotional intelligence and of organizational commitment but also to find the predictive indicators of the job satisfaction among the academia of a technical university in Brunei. In line with the principles of multivariate data analysis, data was screened for outliers. Cases with standard deviation greater than 2 and cases with missing values were removed. The result of regression analysis is presented in Table 5. The model has statistically significant F-ratio and possesses sufficient explanatory power as indicated by $\mathrm{R}^{2}$ coefficient that shows $49 \%$ of the variance in the job satisfaction is explained by the emotional intelligence, and affective component of organizational commitment. From Table 5, it is further evident that two out of seven components of emotional intelligence and one component of organizational commitment (affective) as significant predictors of job satisfaction.

Table 5. Showing regression analysis

\begin{tabular}{lccll}
\hline Variables & Beta & t-value & p-value & Remarks \\
\hline Emotional self awareness & -.329 & 2.468 & .016 & Significant \\
Emotional expression & -.056 & -.445 & .658 & Not Significant \\
Emotional awareness of others & .159 & 1.009 & .317 & Not Significant \\
Emotional reasoning & .120 & .859 & .329 & Not Significant \\
Emotional self management & .382 & 2.964 & .000 & Significant \\
Emotional management of others & .689 & 1.179 & .000 & Not Significant \\
Emotional self control & .001 & .333 & .978 & Not Significant \\
Affective org commitment & .561 & 5.098 & .000 & Significant \\
Continuum org, commitment & .071 & .669 & .506 & Not Significant \\
\hline
\end{tabular}

Notes: Dependent variable: Job Satisfaction; $\mathrm{R}^{2}=.48, \mathrm{~F}=5.58$, -statistically significant. 


\section{Discussion}

The present pioneering study explores the link between emotional intelligence, organizational commitment and job satisfaction. The findings confirm the relationship among these variables proving evidence of the validity of the prior research in establishing positive relationship between these variables.

The study has found a significant correlation between the overall constructs of emotional intelligence, organizational commitment and job satisfaction as shown in Table 6. However, the significance of emotional intelligence variables among the surveyed academics revealed some interesting findings. The study has found that out of the seven dimensions of emotional intelligence, only two i.e. emotional self awareness and emotional self management are related with the job satisfaction. In other words, most of our respondents are concerned about expressing their own emotions. They are not only aware of their emotions but also know how to express and manage them. All other dimensions of emotional intelligence especially knowing other emotions either are not fully understood by the respondents or do not contribute towards job satisfaction. The result supports the majority of the prior studies especially linking EI with job satisfaction. With regards to consideration of two subscales that are significant, our results do corroborate with Eskandarpour and Amiri (2012) who found significant difference between the different dimensions of emotional intelligence and university managers. Similarly, our work further support Joibar (2008) who found a significant relationship among self-motivating, self-awareness and self-control.

Table 6. Showing overall correlation among three constructs

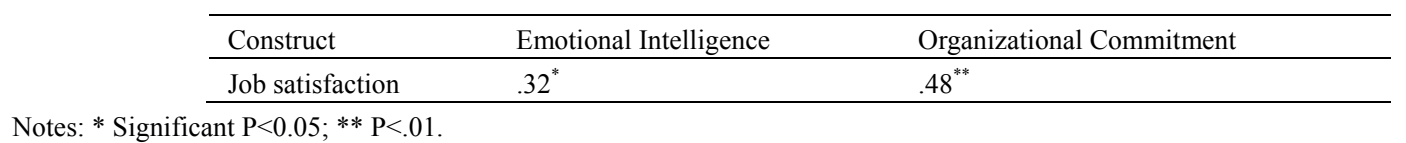

Similarly, the organizational commitment as an overall construct contributed towards the job satisfaction as shown in Table 6; however, our regression analysis in Table 5 indicated that continuance dimension of organizational commitment remained insignificant. This is true as affective commitment (AC) is related to employee's emotional attachment to the organization and as Meyer and Allen (1991) asserted that the components of organizational commitment reflect the different 'mind sets' which can characterize an employee's commitment to the organization. As a result, the respondent is high and significant affective mindset strongly identifies with the goals of the organization and desires to remain a part of the organization. So it will be worth to mention that the academics commit to the university because they 'want to'. Academics with more organizational commitment are more satisfied and the correlation coefficient of these two variables is high and better as compared with emotional intelligence and job satisfaction. Our results are in line with several of prior studies such as Malik et al. (2010); Jofri et al. 2011; Daneshfard and Ekvaniyan (2012) who found high degrees of organizational commitment and job satisfaction.

\section{Conclusion}

This pioneering study has full-filled its objectives. The study was initially designed to provide the empirical evidence of the links between emotional intelligence, organizational commitment and to predict the job satisfaction among academics of a technical university in Brunei Darussalam. Hence the study's findings suggest that EI and job satisfaction would be recognized as an important factor in understanding and predicting the academic job satisfaction. This combination is not only ideal but could further lead to the institution's productivity and would foster the staff turnover and staff satisfaction that is considered as necessary measure to deal with the issue of under staffing in the newly established technical university.

\subsection{Practical Implications}

The study has several practical implications for HR and higher management of the technical university in general and Higher Education Department of Ministry of Education. The newly established technical university was previously running as a technical institution and it's staff are very experienced and are very committed and this should be considered as an asset and thus any attempt to sustain and motivate the commitment of current academics will determine the success of the institution of higher learning. The findings reveal that affective commitment of the academics has relevance with their understanding as how to further strengthen academic and organization linkages. O'Driscoll and Randall (1999) concluded that employees' satisfaction with intrinsic rewards (e.g. job scope, challenges and five job enrichment areas) has strong linkages with the performance. Any attempt to mould the intrinsic rewards with extrinsic rewards such as revise scale or grade will work as elixir for these academics. 


\subsection{Limitations and Future Research}

Like every empirical research based on survey techniques, the present study is not void of limitations. The surveying of the population in itself is subject to criticism. The survey is based on self-reported information that is further exposed to response-bias and the study lacks the methods of controlling this so we suggest that caution should be exercised in generalizing the result. Since the study is based on a single institution so again any attempt in generalizing the results should carefully be made. The results of this study are limited and constrained by the three measures used for this study. While the measures used are accepted as reliable and valid and their selection is defendable, however, the more applied measures (EI, and OC) would reflect different perspectives and can further be used to establish generalization of the study. In addition, the results of this study are bound by the context of the research, we also recommend that future research endeavors be focused on this aspect and replication of this study into different work-settings especially cross-cultural and cross industry will further improve the study results within different perspectives. In the academic perspective future studies should focus on the role of these variables in addition to other organizational variables to predict the academic performance of institutions of higher learning.

\section{Acknowledgements}

We are thankful to Palmer and Stough (2001) for granting us the permission to use the Genos instrument for measuring Emotional Intelligence.

\section{References}

Allen, N. J., \& Meyer, J. P. (1996). Affective, Continuance and Normative Commitment to the Organization: An Examination of Construct Validity. Journal of Vocational Behavior, 49, 252-276. http://dx.doi.org/10.1006/jvbe.1996.0043

Arifin, Y., Mohd, B. H., \& Azhar, H. (2004). The Influence of Emotional Intelligence on Organizational Commitment and Job Satisfaction of Employees in Public and Private Sector. paper presented in Beijing Conference.

Bar-On, R. (1997). Bar-On Emotional Quotient Inventory (EQ-i). Technical Manual Toronto: Multi-Health System.

Bar-On, \& Parker, J. D. (2000). The Handbook of Emotional Intelligence. San Francisco: Jessey-Bass.

Batt, R. (2002). Managing Customer Service, Human Resource Practices, Quit Rates and Sales Growth. Academy of Management Journal, 45, 587-597. http://dx.doi.org/10.2307/3069383

Bedwell, S. (2003). Emotional Intelligence, Personality Revisited or Something Else. Proceedings of Symposium at the Annual Meeting of the Society of Industrial and Organizational Psychology, Orlando, Fl.

Buck, J. M. (1999). The Effect of Human Resource Management Strategy on Level of Organizational Commitment among Staff Employees at Public Institutions of Higher Education. (Unpublished $\mathrm{PhD}$ Dissertation). The University of Mississippi, USA.

Buck, J. M., \& Watson, J. L. (2002). Retaining Staff Employees: The Relationship between Human Resource Management Strategies and Organizational Commitment. Innovative Higher Education, 26(3), 175-194. http://dx.doi.org/10.1023/A:1017916922194

Carmeli, A. (2003). The Relationship between EI and Work Attitude Behavior and Outcomes: An Examination among Senior Managers. Journal of Managerial Psychology, 18(8), 788-813. http://dx.doi.org/10.1108/02683940310511881

Caruso, D. (2004). Defining the inkblot called emotional intelligence. White paper prepared for the Consortium for research on Emotional Intelligence in Organizations. Retrieved from www.eiconsortium.org

Chien-M, H. S. V., \& Chen, K. M. (2012). A Study on the Relationship among Self-motivation, Organizational Commitment and Job Satisfaction of University Faculty Members in Taiwan. International Journal on New Trends in Education and their Implications, 3(3).

Chughtai, A. A., \& Zafar, S. (2006). Antecedents and Consequences of Organizational Commitment. HRM Research, 11(1), 39-64.

Cooper, R. K. (1997). Applying Emotional Intelligence in the Workplace. Training and Development, 51, 31-38.

Cronbach, L. J. (1951). Coefficient Alpha and the Internal Structure of Test. Psychometrika, 16, 297-334. http://dx.doi.org/10.1007/BF02310555 
Daneshfard, C., \& Ekvaniyan, K. E. (2012). Organizational Commitment and job Satisfaction in Islamic Azad University. Interdisciplinary Journal of Contemporary Research in Business, 3(9), 168-181.

Davies, M., Stankov, L., \& Roberts, R. D. (1998). Emotional Intelligence: in Search of an Elusive Construct. Journal of Personality and Social Psychology, 75(4), 989-1015. http://dx.doi.org/10.1037/0022-3514.75.4.989

Dong, Q., \& Howard, T. (2006). Emotional Intelligence, Trust, and Job Satisfaction. Competitive Forum, 4, 381-388.

Eskandarpour, B., \& Amiri, M. (2012). Survey of relationship between dimensions of emotional intelligence and effectiveness of managers of Ardebil Universities. International Research Journal of Applied and Basic Sciences, 3(7), 1369-1374.

Furnham, A., \& Christoforou, I. (2007). Personality Traits, Emotional Intelligence and Multiple Happiness. North American Journal of Psychology, Dec.

Gardner, L., \& Stough, C. (2002). Examining the Relationship between Leadership and Emotional Intelligence in Senior Level Managers. Leadership and Organization Development Journal, 23(2), 68-78. http://dx.doi.org/10.1108/01437730210419198

Gautam, et al. (2005). Organizational Citizenship Behavior and Organizational Commitment in Nepal. Asian Journal of Social Psychology, 8, 305-314. http://dx.doi.org/10.1111/j.1467-839X.2005.00172.x

Gaylor, K. P. (2004). Organizational Commitment in Higher Education: A Multidimensional Perspective. (Unpublished PhD Dissertation). Jackson State University, USA.

George, J. M. (2000). Emotions and Leadership: The Role of Emotional Intelligence. Human Relations, 53(8), 1027-1055. http://dx.doi.org/10.1177/0018726700538001

Goleman, D. (1995). Emotional Intelligence. NY: Bentham.

Goleman, D. (1998). Working with Emotional Intelligence. NY: Bentham.

Goleman, D. (2001). Emotional Intelligence: issues in paradigm building. In C. Cherniss \& D. Goleman (Eds.), The emotionally intelligent workplace: How to select for, measure, and improve emotional intelligence in individual groups and organizations (pp.13-26). New York: Jossey Bass.

Hacket, R. D., Bycio, P., \& Hausdorf, P. A. (1994). Further Assessment of Meyer and Allen (1991) Three Component Model of Organizational Commitment. Journal of Applied Psychology, 79, 15-23. $\mathrm{http}: / / \mathrm{dx}$. doi.org/10.1037/0021-9010.79.1.15

Hackman, J. R., \& Oldman, G. R. (1976). The Job Diagnostic Survey: An Instrument for the Diagnosis of Jobs and the Evaluation of Job Design projects. Yale: Yale University Press.

Hair, J. F., Anderson, R., Tatham, R. L., \& Black, W. C. (1998). Multivariate Data Analysis (4th ed.). Englewood Cliffs, NJ: Prentice-Hall.

Huselid, M. A. (1995). The Impact of Human Resource Management Practices on Turnover, Productivity and Corporate Financial Performance. Academy of Management Journal, 38(3), 635-672. http://dx.doi.org/10.2307/256741

Indoo, S., \& Ajeya, J. (2012). Emotional Intelligence and Occupational Stress among the Faculty Members of Private Medical and Engineering College of Utter Pradesh: A Comparative Study. Advances in Management, 5(7).

Jelondar, S. Y., \& Goodare, F. L. (2012). Teachers' Emotional Intelligence and its Relationship with Job Satisfaction. Advances in Education, 1(1), 4-9.

Jofri, H., Yaccob, H. F., \& Shah, I. M. (2011). The Relationship between demographics variables, emotional intelligence, communication effectiveness, motivation and job satisfaction. International Journal of Academic Research in Business and Social Sciences, 1(1), 35-58.

Joibar, M. (2008). Comparison of emotional intelligence among level of managers of management organization and country planning and sub-organizations. Writing of Management Perspective, seventh year.

Khani-M, K., \& Lalardi, M. N. (2012). Emotional Intelligence and Organizational Commitment between Hotel Staff in Tehran, Iran. American Journal of Business and Management, 1(2), 54-59.

Lawrence, J., OH, M., \& Bell, A. (2011). Faculty Organizational Commitment and Citizenship. Research in 
Higher Education.

Lee, W. S. (2010). The Relationship between Job Characteristics, Job Satisfaction toward Effective Commitment: The Case of Engineers from SSP Sdn. Bhd. Research Report Online MBA, Universiti Sanis Malaysia (USM).

Locke, E. A. (1976). The Nature and Causes of Job Satisfaction. In M. D. Dunnette (Ed.), Handbook of Industrial and Organizational Psychology. Chicago, Ills: Rand McNally.

Malik, M. E., Nawab, S., Naeem, B., \& Danish, R. Q. (2010). Job Satisfaction and Organizational Commitment of University Teachers in Public Sector of Pakistan. International Journal of Business and Management, $5(6), 17-22$.

Meyer, J. P., \& Allen, N. J. (1991). A Three Components Conceptualization of Organizational Commitment. Journal of Vocational Behavior, 14, 224-247.

Meyer, J. P., Stanley, D. J., \& Herscovitch, L. (2002). Affective, Continuance, and Normative Commitment to the Organization: A Meta Analysis of Antecedents, Correlates and Consequences. Journal of Vocational Behavior, 61, 20-52. http://dx.doi.org/10.1006/jvbe.2001.1842

Moynihan, L. M., Boswell, W. R., \& Boudreau, J. W. (2000). The Influence of Job Satisfaction and Organizational Commitment on Executives Withdrawal and Performance. Working Paper-00-16, Cornell University Center for Advanced HR Studies.

Muller, C. W., \& Wallace, J. E. (1992). Employee Commitment: Resolving Some Issues. Work and Occupation, 19(3), 211-237. http://dx.doi.org/10.1177/0730888492019003001

Ngah, R., Jussof, K., \& Rahman, Z. A. (2009). Emotional Intelligence of Malaysian Academics towards Work Performance. International Education Studies, 2(2), 103-112.

Nooraei, M., \& Arasi, I. S. (2011). Emotional Intelligence and Faculties' Academic Performance: The Social Competencies Approach. International Journal of Education Administration and Policy Studies, 2(4), 45-52.

O’Driscoll, M. P., \& Randall, D. M. (1999). Perceived Organizational Support, Satisfaction with Rewards, and Employee Job Involvement and Organizational Commitment. Applied Psychology: An International Review, 48(2), 197-209. http://dx.doi.org/10.1111/j.1464-0597.1999.tb00058.x

Palmer, B. R. (2007). Models and Measures of Emotional Intelligence. Organizations \& People, 14(2), 3-10.

Palmer, B., \& Stough, C. (2001). Workplace SUEIT-Swinburne University Emotional Intelligence Test. Swinburne University, Australia, Organizational Psychology Research Unit.

Palmer, B., Donaldson, C., \& Stough, C. (2002). Emotional Intelligence and Life Satisfaction. Personality and Individual Differences, 33, 1091-1100. http://dx.doi.org/10.1016/S0191-8869(01)00215-X

Patterson, M. G., West, M., Lawthorn, R., \& Nickell, S. (1997). Impact of People Management Practices on Business Performance. London: Institute of Personnel \& Development.

Petrides, K. V., \& Furnham, A. (2000). On the Dimensional Structure of Emotional Intelligence. Personality and Individual Difference, 29(22), 313-320. http://dx.doi.org/10.1016/S0191-8869(99)00195-6

Porter, L., Steers, R., Mowday, R., \& Boulian, P. (1974). Organizational Commitment, Job Satisfaction and Turnover among Psychiatric Technician. Journal of Applied Psychology, 59, 603-609. http://dx.doi.org/10.1037/h0037335

Saif, S. K., Nawaz, A., \& Jan, F. A. (2012). Predicting Job Satisfaction among Academics of Universities in KPK, Pakistan. Industrial Engineering Letters, 2(2).

Salleh, N. (2008). Emotional Intelligence during Change. Proceedings of $9^{\text {th }}$ International Conference in HRD Research and Practice, Lille, France.

Salleh, N. (2009). Leadership and Emotional Intelligence. ITU Regional Human Capacity Development Forum for the Asia Pacific, Rizqun Hotel, Brunei Darussalam.

Salleh, N. (2010). Correlation between Employees' Emotion and Emotional Intelligence during Change in Brunei. Brunei Darussalam Journal of Technology and Commerce, 5(1), 99-104.

Salovey, P., \& Mayer, J. D. (1990). Emotional Intelligence. Imagination, Cognition and Personality, 9, 185-211. http://dx.doi.org/10.2190/DUGG-P24E-52WK-6CDG 
Santhaparaj, S. A., \& Alam, S. S. (2005). Job Satisfaction among Academic Staff in Private Universities in Malaysia. Journal of Social Science, 1(2), 72-76.

Seyal, A. H., Afzaal, T., \& Rajeskar, J. (2011). A Preliminary Examination of the Relationship between Emotional Intelligence, Leadership Style, Personality and Organizational Culture: Evidence from Bruneian SMEs. In the Proceedings of $10^{\text {th }}$ International Conference of the Academy of HRD (Asia Chapter), Kuala Lumpur, Malaysia (December, $3^{\text {rd }}$ to Dec $6^{\text {th }}$ 2011).

Seyal, A. H., Afzaal, T., \& Saun, C. T. S. (2012). Assessing Emotional Intelligence and Organizational Citizenship Behaviour among Executives: Examples from Bruneian SMEs. Journal of International Business Management, 6(4), 476-486. http://dx.doi.org/10.3923/ibm.2012.476.486

Sharon, L. L. (2009). Sampling Design and Analysis. UK: Duxbury.

Shore, L. M., \& Martin, H. J. (1989). Organizational Commitment and Job Satisfaction are More Strongly related to Job Performance. Human Relations, 42. http://dx.doi.org/10.1177/001872678904200705

Sial, M. A., Jilani, S. M. A., Imran, R., \& Zaheer, A. (2011). Effect of Human Resources Practices on Organizational Commitment in Pakistani Universities. World Applied Science Journal, 45, 587-597.

Smith, P. L., Smits, S. J., \& Hoy, F. Y. (1998). Employee Work Attitudes: The Subtle Influence of Gender. Human Relations, 51(5), 649-666. http://dx.doi.org/10.1177/001872679805100504

Spector, P. E., Dwyer, D. J., \& Jex, S. M. (1988). The Relationship of Job Stressor to Affective Health and Performance Outcomes: A Comparison of Multiple Data Source. Journal of Applied Psychology, 73, 11-19. http://dx.doi.org/10.1037/0021-9010.73.1.11

Ssesanga, K., \& Garrett, M. R. (2005). Job Satisfaction of University Academic: Perspective from Uganda. Higher Education, 50, 33-56. http://dx.doi.org/10.1007/s10734-004-6346-0

Sy, T., Tramm, S., \& O’Hara, L. A. (2006). Relationship of Employee and Manager Emotional Intelligence to Job Satisfaction and Performance. Journal of Behavior, 68(3), 461-473.

Tanriverdi, H. (2008). Worker's Job Satisfaction and Organizational Commitment Factors. Journal of American Academy of Business, 14(1).

Wright, T. A., \& Crapanzano, R. (2000). Emotional Regulatory in Workplace: Anew Way to Conceptualize Emotional Labor. Journal of Occupational Health Psychology, 5(1), 85-94.

Zadel, A. (2008). Do Emotionally Intelligent Leaders Have More Satisfied Employees? International Journal of Management and Enterprise Development, 5(5), 590-608. http://dx.doi.org/10.1504/IJMED.2008.019085 